\title{
Effects of Curcumin on Mitochondria in Neurodegenerative Diseases
}

Running Title: Curcumin, mitochondria and neurodegeneration

\author{
Bagheri $\mathrm{H}^{1}$, Ghasemi $F^{2}$, Barreto $\mathrm{GE}^{3,4}$, Rafiee $\mathrm{R}^{5}$, Sathyapalan $\mathrm{T}^{6}$, Sahebkar $\mathrm{A}^{7,8,9}$ \\ 1 Department of Biotechnology, Faculty of Medicine, Arak University of Medical Sciences, Arak, Iran. \\ 2 Blood Transfusion Research Center, High Institute for Research and Education in Transfusion \\ Medicine, Tehran, Iran. \\ 3 Department of Biological Sciences, University of Limerick, Limerick, Ireland. \\ 4 Health Research Institute, University of Limerick, Limerick, Ireland. \\ 5 Sciences and Research Branch, Islamic Azad University, Tehran, Iran. \\ 6 Department of Academic Diabetes, Endocrinology and Metabolism, Hull York Medical School, \\ University of Hull, Hull, UK \\ 7 Neurogenic Inflammation Research Center, Mashhad University of Medical Sciences, Mashhad, Iran \\ 8 Biotechnology Research Center, Pharmaceutical Technology Institute, Mashhad University of Medical \\ Sciences, Mashhad, Iran. \\ 9 School of Pharmacy, Mashhad University of Medical Sciences, Mashhad, Iran.
}

This is the peer reviewed version of the following article: Bagheri, H, Ghasemi, F, Barreto, GE, Rafiee, R, Sathyapalan, T, Sahebkar, A. Effects of curcumin on mitochondria in neurodegenerative diseases. BioFactors. 2019; 1- 16, which has been published in final form at https://doi.org/10.1002/biof.1566. This article may be used for non-commercial purposes in accordance With Wiley Terms and Conditions for self-archiving. 


\begin{abstract}
Neurodegenerative diseases (NDs) result from progressive deterioration of selectively susceptible neuron populations in different central nervous system (CNS) regions. NDs are classified in accordance with the primary clinical manifestations (e.g. parkinsonism, dementia or motor neuron disease), the anatomic basis of neurodegeneration (e.g. frontotemporal degenerations, extrapyramidal disorders or spinocerebellar degenerations) and fundamental molecular abnormalities (e.g. mutations, mitochondrial dysfunction and its related molecular alterations). NDs include the Alzheimer disease (AD), Parkinson disease (PD) among others. There is growing evidence that mitochondrial dysfunction and its related mutations in the form of oxidative/nitrosative stress and neurotoxic compounds play major roles in the pathogenesis of various NDs. Curcumin, a polyphenol and nontoxic compound, obtained from turmeric, has been shown to have a therapeutic beneficial effect in various disorders especially on the CNS cells. It has been shown that curcumin has considerable neuro- and mitochondria-protective properties against broad-spectrum neurotoxic compounds and diseases/injury-associating NDs. In this article, we have reviewed the various effects of curcumin on mitochondrial dysfunction in NDs.
\end{abstract}

Keywords: Curcumin; Neurodegenerative Diseases; Mitochondrion; Mitochondrial dysfunction; Neuroprotection. 


\section{Introduction}

Turmeric (Curcuma longa L.) is a common golden-colored spice from a member of the ginger family (Zingiberaceae) which is a rhizomatous herbaceous perennial flowering plant (Angiosperms) (1, 2). The powdered rhizome of turmeric has been used in traditional medicine as a curative compound as well as in Asian cuisines as a food additive and beverage industries as a coloring agent $(3,2)$. Curcuminoids are biologically active and are one of the main components of turmeric, which based on soil conditions and origins, contain $2 \%$ to $9 \%$ of the turmeric compounds. Curcuminoids consist of curcumin/diferuloylmethane (the major component), demethoxycurcumin, bis-demethoxycurcumin and cyclic curcumin (the minor component) $(4,2)$.

Over the past half a century, curcuminoids in particular curcumin, have displayed a growing interest in a broad range of biological/pharmacological research. The anti-bacterial properties of curcumin were reported for the first time in $1949(5,6)$. Since then growing number of studies have focused on the potential therapeutic properties of curcumin in a myriad conditions and shown to have antioxidant (7), anti-tumoral $(8-10,3,1)$, lipid-modifying $(11,12)$, hepatoprotective $(13$, 14), vasculoprotective (15), cardioprotective (16), pulmonoprotective (17), neuroprotective (18), anti-thrombotic (19), immunomodulatory (20, 21), anti-diabetic (22), analgesic (23), antiinflammatory especially anti-neuroinflammatory (24-27) as well as microglia-activation inhibitory (2) properties.

Curcumin (1,7-bis-(hydroxy-3-methoxyphenyl)-1,6-heptadiena-3,5-dione; $\mathrm{C}_{21} \mathrm{H}_{20} \mathrm{O}_{6}$ ) is a natural polyphenol compound with molecular weight of $368.38 \mathrm{~g} / \mathrm{mol}$. It contains two ferulic acid residues joined by a methylene bridge $(28,6)$. It is a hydrophobic molecule, mostly insoluble in water, poorly soluble in hydrocarbon solvents (e.g. cyclohexane, hexane) and easily soluble in polar solvents (e.g. ethanol, methanol, DMSO, acetonitrile, chloroform, ethyl acetate) (6). Biological activities and therapeutic properties of curcumin take place in three functional groups: an aromatic o-methoxy phenolic group, $\alpha, \beta$-unsaturated $\beta$-diketo moiety and a seven carbon linker (28). In addition to its various therapeutic properties, owing to the hydrophobic tendency, presence of an active methylene group and a $\beta$-diketone moiety, curcumin has poor bioavailability/pharmacokinetics and degraded easily via aldo-keto reductase in the liver (29, 2). Numerous studies are being conducted to improve the bioavailability and pharmacokinetics property of curcumin.

NDs are a heterogeneous group of disorders that are characterized by the progressive deterioration of the function and structure of the selectively vulnerable neuron populations in the CNS (30). NDs are showing a growing trend worldwide as well as worsening mortality and morbidity especially in the elderly (31). The individual NDs can be classified by their clinical presentations and symptoms, with pyramidal and extrapyramidal movement impairments (also known as ataxias) and cognitive or behavioral impairments (also known as dementia) being the most common (32, 33). NDs comprise AD, PD and PD-related disorders, Huntington disease (HD), Spinal muscular atrophy (SMA), amyotrophic lateral sclerosis [ALS; also known as motor neuron 
diseases (MND)], dementia with Lewy bodies (DLB), Spinocerebellar ataxia (SCA), corticobasal degeneration (CBD), Frontotemporal dementia (FTD) and its variants, progressive supranuclear palsy (PSP), Prion disease and other dementia/ataxia-related NDs (34). NDs are mostly incurable and the current therapeutic strategies are aimed at symptomatic relief and/or restraining the disease progression (35). NDs not only reduce the life expectancy and health-related quality of life (HRQoL) in patients but also take a heavy toll on family members and impose striking financial strains on global healthcare systems $(36,37)$. Hence, it is an urgent necessity to develop more effective therapeutic strategies to cope with the growing burden and health-related consequences of NDs.

NDs are characterized by many micro-processes resulting in progressive neuronal dysfunction and death. These include specific protein accumulations, mitochondrial dysfunction, oxidative/nitrosative stress, proteotoxic stress and its related abnormalities in ubiquitin proteasomal and autophagosomal/lysosomal systems, excitotoxicity, apoptosis (also known as programmed cell death) and uncontrolled neuroinflammation (38-41). There is overwhelming evidence of mitochondrial dysfunction and mutations in the pathogenesis of various NDs. Mutations in the mitochondrial DNA (mtDNA), impaired mitochondria dynamics (e.g. shape, size, distribution, fission-fusion, movement), abnormalities in complexes of the electron transport chain (ETC) and partial inhibition of mitochondrial ATP production giving rise to overproduction of free radicals. This will lead to damage of the biomolecules (e.g. lipids, proteins and DNA), neuroinflammation, tissue damage and consequent cellular apoptosis in CNS which are the major hallmarks of NDs $(40,42)$.

It has been reported that native curcumin and its micellized (43)/micronized (44)/hybridized (45)/nano-sized (46) forms, as well as its derivatives (47)/synthetic analogs (48) and its synergistic combination with other compounds (49) have the excellent capacity for scavenging intracellular reactive oxygen species (ROS) and reactive nitrogen species (RNS) $(50,51)$. In addition, it protects the mitochondrial dysfunctions/impairments by 1 . retaining mitochondrial membrane potential $(\Delta \Psi \mathrm{m}) /$ the activities of all four mitochondrial complexes (complex I, II, III and IV) (48) and Bax/Bcl-2 ratio (52); 2. enhancing/increasing mitochondrial fusion activity, mitochondrial biogenesis and synaptic proteins (53); 3. reducing fission machinery (53), mitochondrial swelling, lipid peroxidation, protein carbonylation (44), levels of oxidized lipids (49) neuroinflammation (54), apoptosis (55-57), cytochrome c, caspase-3 and -9 activation and mitochondrial depolarization (58); 4. modulating/targeting the phospho-CREB-BDNF signaling (54) and the nuclear factor (erythroid-derived 2)-like 2 (also known as Nrf2 or NFE2L2; a transcription factor) (59) and 5. restoring the glutathione (GSH) levels and superoxide dismutase (SOD) (44).

These findings suggest that utilizing curcumin and its related compounds as a neuroprotective agent with modulatory/protective effects on mitochondrial impairments and mitophagy (60) could be a promising approach for the treatment of NDs. Due to the association between NDs and mitochondrial dysfunction, we review in detail about the effects and underlying mechanisms of curcumin on the mitochondria in NDs in vitro, in vivo and in clinical trials. 


\section{Neurodegenerative Diseases}

At present, there is no definitive treatment for curing the NDs. , The current therapeutic strategies are just capable of symptomatic relief and/or managing the overall symptoms as well as restraining the disease progression such as dopaminergic treatments for parkinsonism (e.g. PD, PD-related disorders and movement impairments) (61), cholinesterase inhibitors for cognitive disorders (62), antipsychotic drugs (also known as neuroleptics or major tranquilizers) for behavioral and psychological symptoms of dementia (63), analgesics for pain reduction (64), anti-inflammatory medications for ameliorating disease progression (2), and deep-brain stimulation, a medical device, to stop tremor and refractory movement disorders (65).

Although recent advances have shed more light into the pathophysiology of NDs, the exact etiology of NDs remain to be fully elucidated. The etiology of NDs could be multifactorial and heterogeneous, albeit credible evidence has emphasized that aging, genetic background, accumulated/misfolded proteins and environmental/external factors (e.g. lifestyle and chemical exposure) are potentially linked with the onset of these diseases $(66,67)$.

The NDs are typically described by specific misfolded and aggregated proteins (68); however, the affected neuron populations and disease severity differ for each NDs (41). However, NDs share many substantial micro-processes associated with gradual neuronal dysfunction and death such as proteotoxic stress and its related abnormalities in ubiquitin-proteasomal and autophagosomal/lysosomal systems, synaptic toxicity, excitotoxicity, oxidative stress, apoptosis, cell-death-related signaling pathways and neuroinflammation (33, 54).

$\mathrm{AD}$ is the most common form of dementia with a growing impact on NDs-related global health challenges affecting more than 50 million individuals. It is projected that AD cases in 2030 and 2050 will rise to 82 and 152 million respectively (69). A $\beta$ peptides accumulation and their deposition into $\beta$-amyloid plaques (also known as $A \beta$ plaques), as well as the neurofibrillary tangles aggregation into misfolded and hyperphosphorylated tau protein, are the leading causes and the accelerator of AD and AD-related pathology (41). Neurotoxic metals (e.g. lead, mercury, aluminum, cadmium, arsenic), as well as metal-based nanoparticles and some pesticides, are reported to increase $A \beta$ peptides and the neurofibrillary tangles aggregation. This leads to $A \beta$ plaques and hyperphosphorylation of Tau protein and the consequent onset of AD and AD-related pathology (67). Energy deficiency due to mitochondrial dysfunction is a crucial characteristic of $\mathrm{AD}$ and $\mathrm{AD}$-related dementias.

PD and PD-related disorders are the second most common NDs with more than 6 million cases or 1-2 individual per 1000 of the population worldwide affected (70). This group of disorders predominately affect dopaminergic (dopamine-producing) neurons in a specific area of the brain called substantia nigra (41). The exposure to several metals (e.g. lead and manganese), industrial chemicals and pollutants (71), solvents and some pesticides (72) are significantly associated with the mitochondrial dysfunction, metal homeostasis alterations and proteins aggregation such as asynuclein, which is a key constituent of DLB and a pivotal factor in PD pathogenesis (67). 
Moreover, nuclear genome mutations in the PINK1 and Parkin genes have been implicated in PDrelated NDs pathology (73). DLB is the second most common dementia which is characterized by progressive cognitive impairment, psychiatric and behavioral disturbances and parkinsonian motor symptoms (74).

HD is an autosomal dominant neurodegenerative disorder with choreoathetosis, behavioral as well as psychiatric disturbances and dementia that is caused by excessive CAG repeats in the short arm of chromosome 4p16.3 in the Huntingtin gene. The more CAG repeats (36 CAG repeats or more) the earlier will be the onset of the disease $(75,76)$. Prion disease is a group of rare NDs that can affect both humans and animals (77). Prion is a type of protein that can fold abnormally leading to the onset of prion disease which is also known as transmissible spongiform encephalopathies.

FTD is an umbrella term given to a heterogeneous group of clinical syndromes and is the leading cause of early-onset dementia in patients under 65. It results from neurodegeneration within the frontal and anterior temporal lobes, insular cortex and subcortical structures. The major hallmarks of FTD are early changes in emotion and behavior, language, and motor skills (31). ALS/MND is a fatal motor neuron disorder that is characterized by progressive deterioration of the upper and lower motor neurons at the spinal or bulbar level (78). The exact etiology of ALS/MND remains to be elucidated. Mutations of superoxide dismutase 1 have been proposed as the most common cause of this fatal motor neuron disorder (79).

\section{The Roles of Mitochondria in NDs}

Although the adult brain is about $2 \%$ of the body mass, it consumes more than $20 \%$ of energy supply in the form of ATP. Most of the brain energy is consumed for synaptic transmission which is crucial for synaptic plasticity (80). Mitochondria are dynamic organelles and the powerhouses of cells. The mitochondria are not only responsible for production of the majority of energy currency represented by ATP but also have a variety of crucial roles including regulation of calcium homeostasis, biogenesis of haem, fatty acid synthesis, biogenesis of iron-sulfur (Fe-S) proteins, apoptosis and population maintenance through fission and fusion $(81,82)$. There is overwhelming evidence that mitochondrial dysfunction and mutations play major roles in the aging and pathogenesis of various NDs (42).

Brain-derived neurotrophic factor (BDNF) pathway is a fundamental pathway for regulating the synaptic transmission and plasticity of neurons. These processes require a high amount of energy consumption and $\mathrm{ca}^{2+}$-buffering. For $\mathrm{ca}^{2+}$-buffering, mitochondria must be moved to the proper locations. The role of the BDNF pathway in mitochondrial movement and distribution has been increasingly recognized. This suggests that mitochondrial movement and distribution play a crucial role in BDNF-mediated synaptic transmission and plasticity (83). Hence, impairment of mitochondria could affect the synaptic transmission and synaptic plasticity which are the important neurochemical foundation of learning and memory. Intensifying the BDNF pathway could be associated with a higher mitochondrial movement and distribution. 
The cAMP response element-binding (CREB) protein is a ubiquitous transcription factor. After phosphorylation, it can promote the transcription of cAMP response element-regulated genes especially mitochondrial genes and it related protein biogenesis (84). However, dysregulation of the CREB transcriptional cascade is reported that have a direct link with the mitochondrial dysfunction and the progression of NDs (85).

The human mtDNA contains genetic coding information of 13 proteins which are the core constituents of the mitochondrial electron transport chain (ETC) complexes I-IV that are embedded in the inner membrane (86). ETC is one of the major hallmarks of mitochondria for energy production in cells through the redox (reduction and oxidation) reactions. Since the major part of ATP is generated by ETC the proper functioning of this chain is fundamental for the CNS cells. Dysfunction in ETC complexes via genetic or exogenous factors could contribute greatly to the onset of NDs. It is reported that neurotoxin 1-methyl-4-phenyl-1,2,3,6-tetrahydropyridine (MPTP) suppresses the protein NADH-CoQ reductase in Complex I from pumping the protons across the mitochondrial membrane leading to inhibition of the electrochemical gradient formation and subsequent hindering ATP production and energetic failure (87).

In addition to mtDNA mutations, nuclear DNA mutations are also associated with mitochondrial dysfunction and subsequent NDs. It is reported that nuclear genome mutations in genes encoding $\alpha$-synuclein, parkin (88), PINK1 (89) and LRRK2 (90) lead to a molecular link between mitochondrial dysfunction and subsequent oxidative stress contributing to PD and PD-related NDs pathology. Mutations in amyloid protein precursor (APP), presenilin-1 (PSEN1) and presenilin-2 (PSEN2) genes cause autosomal dominant forms of early-onset AD (91). PSEN1 and PSEN2 mutations impact the mitochondrial function by deregulating the $\mathrm{ca}^{2+}$ signaling leading to mitochondrial metabolic defects (92). On the other hand, APP mutations lead to a serious reduction in respiratory activity and enhance glycolysis as well as reduce the mtDNA transcripts (93).

ETC is responsible for most of the ROS production in the cells. GSH and SOD are the natural antioxidants in the cells especially in mitochondria responsible for ROS scavenging. Several studies have reported that patients with NDs have a significant reduction of these antioxidants (94). On the other hand, mitochondria dysfunction leads to an increase in the levels of lipid peroxidation and protein carbonylation which has been identified as the potential intensifier of ROS and/or freeradical productions $(95,96)$.

Nrf2, a basic leucine zipper protein, is amongst the most pivotal cell defense mechanisms against exogenous and/or endogenous stressors. Nrf2 targets variety of genes such as a vast range of antioxidant enzymes, proteins bound up in xenobiotic detoxification, repair and damaged-proteins elimination, inhibition of neuroinflammation as well as other targeted transcription factors which have fundamental role in retaining the cellular redox homeostasis by regulation, utilization, and generation of GSH and NADPH (97). It is reported that Nrf2 defends neurons against mitochondrial neurotoxic compounds, reduced GHS and imbalanced mitochondrial ROS production as well as improving the function and integrity of mitochondria. Besides, in many 
mitochondrial-related disorders especially NDs the function of Nrf2 is suppressed by several processes $(98,59)$.

$\Delta \Psi \mathrm{m}$ generated by proton pumps of ETC complexes I, III and IV is a fundamental component of mitochondria. It results from the redox reactions associated with the activity of the Krebs cycle and is responsible for the storage of energy. $\Delta \Psi \mathrm{m}$ plays a crucial role in mitochondria homeostasis by eliminating mitochondria dysfunction. The association of proton gradient $(\Delta \mathrm{pH})$ and $\Delta \Psi \mathrm{m}$, form the transmembrane potential of hydrogen ions and can harness ATP production. The levels of $\Delta \Psi \mathrm{m}$ and ATP production are relatively steady with limited fluctuations leading to normal physiological activity (99). Alterations of mitochondrial function such as reduction of $\Delta \Psi \mathrm{m}$ is highly linked to generating more oxidative stress-inducing early apoptosis (100). In short, longterm decline or the rise of $\Delta \Psi \mathrm{m}$ levels may promote adverse effects on cell viability and could be a reason for generating various pathologies especially NDs in CNS (101).

Mitochondria also play a prominent role in the extrinsic/death receptor and intrinsic/mitochondrial apoptosis pathway, which is a fundamental process for growth, homeostasis and immunomodulation in mammalian cells. Apoptosis is initiated by multiple forms of cellular stress stimuli/DNA damage including oxidative stress/ROS/RNS and endoplasmic reticulum stress, radiation and drugs (e.g. chemotherapeutic agents) $(102,40)$. In this process, pro-apoptotic Bcl-2 homology domain 3 only (BH3-only) proteins (e.g. Bad, Bid, Bim and NOXA) activate Bcl-2 proapoptotic family members (e.g. Bax and Bak) and consequently they translocate to the mitochondria. Bax and Bak also induce the cytochrome c release into the cytosol. This promotes the assembling of apoptosome (Apaf-1 and caspase-9) and subsequent activation of executioner caspase-3, -6, -7 initiating the cell death. Moreover, Bcl-2 family has a group of anti-apoptotic members such as $\mathrm{Bcl}-2, \mathrm{Bcl}-\mathrm{xL}, \mathrm{Mcl}-1$ and $\mathrm{Bcl}-\mathrm{w}$. For the proper functioning of the cells, the ratio between anti-apoptotic (e.g. Bcl-2, Bcl-xL) and pro-apoptotic (e.g. Bax and Bak) members of $\mathrm{Bcl}-2$ family proteins must be steady. Unbalancing the anti-apoptotic and pro-apoptotic members of Bcl-2 family proteins leads to neuronal damage/death and NDs $(103,104)$. Moreover, the extrinsic pathway can also crosstalk to the intrinsic apoptosis pathway by an amplification induced by caspase-dependent activation of Bid protein (105).

Microglial cells are the innate immune system cells residing in the CNS. In circumstances such as an invasion of pathogens and the formation of $\mathrm{A} \beta$ plaques, microglial cells are converted to the activated state. To defend against the pathogenic invaders and eliminate the $\mathrm{A} \beta$ plaques, activatedmicroglia have the capability of generating neuroinflammation by releasing broad-range of compounds such as inflammatory mediators and neurotoxic compounds. These compounds are a double-edged sword for defending the neurons or affecting the neurons viability and CNS integrity. The chronic expression of several compounds such as TNF- $\alpha$, IL-1 $\beta$, PGE2, IL-6, IFN$\gamma$, ROS and RNS could be destructive to cells $(106,2)$. Long-standing neuroinflammation and chronic expression of several compounds will strikingly affect the neuronal viability and the survival of neural precursor cells by unbalancing the anti-apoptotic and pro-apoptotic members of Bcl-2 family proteins and targeting mitochondria as well as extrinsic and intrinsic apoptosis 
pathway (107, 108). Moreover, astrocytic mitochondrial dysfunction including change in intracellular calcium, GSH, SOD and specific neurotoxic compounds production have been implicated by various studies to be associated with the onset of NDs (109).

In short, mitochondrial impairments/dysfunction in the CNS neurons results in mitochondrial depolarization and reduction of mitochondrial dynamics/movements, distribution and fission, as well as releasing cytochrome c/ROS/RNS and subsequent neuronal damage and apoptosis. Moreover, many genetic alterations and related suppression on proteins production are associated with a higher incidence of mitochondrial dysfunction and its molecular consequences. Hence, mitochondrion and its related abnormalities are promising therapeutic targets for neurological disorders and NDs (Figure 1).

\section{Molecular Targets of Curcumin on mitochondria in NDs}

It has been shown that many exogenous and endogenous factors such as aging, nuclear- and mtDNA mutations, drugs, neurotoxic compounds and misfolded/aggregated proteins, leads to mitochondria dysfunction, which is markedly linked to the onset and pathogenesis of NDs (30). NDs have a significant effect on the life expectancy and HRQoL (37); however, the existing medications are just capable of symptomatic relief or managing the overall symptoms. It is a priority to develop more effective drugs to face the growing trend of mortality and morbidity of NDs. Curcumin is a natural polyphenol and nontoxic compound stemmed from Curcuma longa L., which has a highly pleiotropic and broad-range of targets in cells especially the cell-relating to NDs. Moreover, curcumin's structure makes it possible to cross the blood-brain barrier (BBB) (2). There is growing evidence on the beneficial therapeutic properties of curcumin on various aspects of cells associated with NDs especially for their dysfunctional/impaired mitochondria (Table 2). In this section, we discuss the molecular targets of curcumin on mitochondria in NDs.

Various neurotoxic compounds and/or drug are increasingly being recognized as external risk factors linked to the mitochondria-mediated onset of various NDs. For instance, long-term alcohol abuse induces oxidative stress, activates the neuroinflammation pathways, increases the caspase3, $-9,-8$ and also changes the Bcl-2/Bax ratio (decreases $\mathrm{Bcl}-2$ and increases Bax proteins). Mitochondria are responsible for regulating the neurotoxicity induced by long-term alcohol abuse, however, these compounds promote the cytochrome c and decrease mitochondria biogenesis (110112). Curcumin has neuro- and mitochondria-protective effects by reversing the withdrawal effects of the alcohol-induced neurodegeneration and also improves neuronal survival by reducing apoptosis, oxidative stress, neuroinflammation and perturbation in phospho-CREB-BDNF signaling. Moreover, curcumin improves the alcohol-induced reduction in the SOD, GSH, oxidized GSH and GSH reductase activity. Curcumin also decreases the levels of TNF- $\alpha$ and IL$1 \beta$ as well as reduces the Bax and Bax/Bcl-2 ratio (54).

Oxaliplatin, a platinum-based anti-cancer chemotherapy drug has dose-limiting side effects on the mitochondria by mediating the oxidative stress leading to damage the neurons $(113,114)$. Combination of curcumin and quercetin have demonstrated neuro- and mitochondrial-protective 
effects against oxaliplatin side effects by significantly reducing the mitochondrial lipid peroxidation levels, protein carbonyl content and subsequent oxidative stress. It also improves the altered non-enzymatic and enzymatic antioxidants and ETC complexes enzymes of mitochondria (114).

Exposure of tert-butyl hydroperoxide (t-BHP) to neurons leads to $\Delta \Psi \mathrm{m}$ loss and cytochrome c release and subsequent activation of caspase-3 and PARP cleavage and cell apoptosis. Curcumin has neuro- and mitochondrial-protective effects by abrogating the $\Delta \Psi \mathrm{m}$ loss and cytochrome c release, suppressing the caspase-3 activation and altering the of $\mathrm{Bcl}-2$ family expression as well as preventing the cellular GSH and decreasing intracellular ROS generation. In short, curcumin has the potential to attenuate tBHP-induced apoptosis in cortical neurons (115).

$\mathrm{A} \beta$ and APP can impair the mitochondria by localizing in the mitochondria membrane, interacting with mitochondrial proteins, disrupting the ETC and following synaptic activity reduction, increasing reactive oxygen species production, reducing the mitochondrial biogenesis and fusion activity, leading to mitochondrial and neuronal damage and consequent NDs $(116,49)$. It has been reported that curcumin can reverse the A $\beta$-withdrawal (and maybe APP-withdrawal) effects by reducing the mitochondrial dysfunction and its fission machinery, improving mitochondrial fusion activity and maintaining cell viability and mitochondrial dynamics, mitochondrial biogenesis, synaptic activity and synaptic proteins (53).

Rotenone, an insecticide and pesticide, has the potential to impair the cognitive function, affect the oxidative defense (e.g. by increasing lipid peroxidation, nitrite concentration and decreasing activity of superoxide dismutase, catalase and reduced glutathione level) and also influence the mitochondrial complex (II and III) enzymes activities $(117,118)$. It is reported that curcumin has the neuro- and mitochondrial-protective against rotenone-withdrawal effects by improving the behavioral alterations, mitochondrial ETC complexes enzyme activities, reducing ROS production and oxidative damage, preventing apoptosis as well as restoring the motor deficits and $\Delta \Psi \mathrm{m}$ and enhancing the antioxidant enzymes $(48,118)$.

D-galactose, a reducing sugar, have the potential of inducing oxidative stress resulting in an alteration in mitochondrial dynamics and apoptosis of neurons. Additionally, D-galactose can impair the activity of the mitochondrial ETC complexes I, II and III. It also significantly increases the lipid/protein oxidation, diminish the levels of GSH and activate the caspase-3 $(119,49)$. Curcumin can markedly reduce the D-galactose effects on CNS cells by restoring the activity of the mitochondrial ETC complexes I, II and III, decreasing the levels of malondialdehyde, advanced oxidation protein products and protein carbonylation, increasing the GSH and oxidized GSH and reducing the expression of cleaved caspase-3 (49).

Various misfolded and aggregated proteins lead to the onset and progression of NDs. $\alpha$-synuclein, an expressed neuronal protein, is the main protein affected in a group of neurodegenerative disorders called $\alpha$-synucleinopathies, which are characterized by the presence of intracellular $\alpha$ synuclein aggregation. $\alpha$-synuclein can potentially lead to the onset of dementia in DLB, PD and 
PD-related disorders $(120,121)$. $\alpha$-synuclein aggregation leads to the induction of the cell death, intracellular ROS production, caspase-3 and -9 activations, mitochondrial depolarization and cytochrome c release. Curcumin has neuro- and mitochondrial-protective properties against the aggregated- $\alpha$-synuclein neurotoxicity by reducing the cell death, intracellular ROS, caspase- 3 and -9 activations, mitochondrial depolarization and cytochrome c release (58).

Hydrogen peroxide $\left(\mathrm{H}_{2} \mathrm{O}_{2}\right)$ is the major source of oxidative stress and is considered to have a major role in various neurological disorders especially NDs. $\mathrm{H}_{2} \mathrm{O}_{2}$ has the potential ability to induce ROS production, apoptosis, caspase- 3 and -9 activations and lipid peroxidation, reduce the mitochondrial depolarization, GSH and GSH peroxidase and increase the intracellular and extracellular release of $\mathrm{ca}^{2+}$. It was reported that curcumin has the neuro- and mitochondrialprotective ability by reversing the detrimental effects of $\mathrm{H}_{2} \mathrm{O}_{2}$ (122).

1-methyl-4-phenylpridinium ions $\left(\mathrm{MPP}^{+}\right)$, the active metabolite of 1-methyl-4-phenyl- 1,2,3,6tetrahydropyridin, exerts its neurotoxicity by inhibiting ATP production, stimulating superoxide radical formation, leading to mitochondria dysfunction and consequent CNS cell death (123). Curcumin significantly protects $\mathrm{CNS}$ cells against $\mathrm{MPP}^{+}$-induced apoptosis. It also improves the mitochondrial function by attenuating the $\Delta \Psi \mathrm{m}$ dysfunction and intracellular ROS production and expression of Bcl-2 (56).

Glutamate is the major excitatory neurotransmitter in the CNS. A mounting number of evidence suggests that perturbations in the systems using the excitatory L-glutamate may underlie the pathogenic mechanisms of a myriad of diseases such as epilepsy and chronic NDs. All neurons in the CNS have the N-methyl-d-aspartate subtype of ionotropic L-glutamate receptors mediating the post-synaptic $\mathrm{Ca}_{2}{ }^{+}$influx. Excitotoxicity resulting from the activation of NMDA receptors leads to the upregulation of GSH peroxidase 1, GSH disulfide, $\mathrm{Ca}_{2}+$ influx, $\mathrm{NO} / \mathrm{ROS} / \mathrm{H}_{2} \mathrm{O}_{2}$ production, cytochrome c release, Bax/Bcl-2 ratio, caspase-3 activity, lactate dehydrogenase and malondialdehyde. It also downregulates GSH, GSH reductase, SOD and catalase thereby promoting cell apoptosis $(124,125)$. Curcumin has been shown to effectively protect CNS cells by reversing all the described glutamate-induced oxidative toxicity and excitotoxicity (125).

Neurotoxic compounds such as manganese and aluminum have the capability to enhance the ETC activity of NADH dehydrogenase (complex I), succinic dehydrogenase (complex II) and cytochrome oxidize (Complex IV), increase the malondialdehyde, ROS production as well as induce mitochondria-related apoptosis such as caspase-3 and -9 activations, cytochrome c release and Bcl-2/Bax ratio (Bax increase, and Bcl-2 decrease). Curcumin exerts its neuro- and mitochondrial-protective effects on CNS cells especially microglial cells by reversing the effects of manganese- and aluminum-induced cytotoxicity/neurocytotoxicity $(126,57)$.

Nrf2 has a pivotal role in defending the CNS cells against the mitochondrial dysfunction and its neurotoxic compounds, reduced GHS and imbalanced mitochondrial ROS which is suppressed in NDs. Curcumin activates Nrf2 and Nrf2 target genes in the CNS cells decreases the level of intracellular ROS and attenuates the oxidative damage and mitochondrial dysfunction (127). 
Cerebral ischemia can induce a rapid increase in lipid peroxidation and reduction in $\Delta \Psi \mathrm{m}$, increase cytochrome c release and caspase- 3 activation thereby resulting in apoptosis. Cerebral ischemia also induces extensive neuronal death together with increasing the astrocytes and microglial cells activation. However, it has been reported that curcumin exerts its neuro- and mitochondrialprotective effects against ischemia-induced neurodegeneration by attenuating ischemia-induced neuronal death and glial activation as well as decreasing the lipid peroxidation, mitochondrial dysfunction and thereby apoptosis (55).

\section{Curcumin analogs}

Despite the myriad therapeutic beneficial effects of curcumin due to its hydrophobic tendency, presence of an active methylene group and a $\beta$-diketone moiety, curcumin has a poor bioavailability/pharmacokinetics and get metabolized easily via aldo-keto reductase in the liver, which hinders its in vivo and clinical trial use in many routes of administration (29, 2). Numerous studies have been looking into mechanisms to circumvent the unstable and poor bioavailability and pharmacokinetic properties of curcumin by designing and characterizing micellized (43)/micronized (44)/hybridized (45)/nano-sized (46) forms of native curcumin as well as its derivatives (47) and synthetic analogs (48).

Modification of curcumin not only enhance its bioavailability status but also amplify the neuroand mitochondrial-protective effects of curcumin. For instance, curcumin pyrazole derivatives (e.g. C1-C6 and CNB-001) have significantly more protective properties on mitochondrial dysfunction and it related abnormalities by inhibiting the $\Delta \Psi \mathrm{m}$ loss, attenuating intracellular ROS and enhancing nuclear translocation of $\operatorname{Nrf} 2(48,59)$.

Curcumin micelles have been shown to have a better bioavailability status by improving solubility in different cells membranes. It has been shown that some micelles considerably improve the curcumin bioavailability up to 40-fold. Moreover, curcumin micelles are more effective in preventing mitochondrial swelling and oxidative stress than native curcumin (43).

Hybridization of compounds to curcumin is another approach to overcome its poor bioavailability and also potentially intensify the neuro- and mitochondrial-protection by another therapeutic compound. It is reported that curcumin and melatonin hybridization (two natural compounds) can potentiate the curcumin bioavailability and its function and can cross BBB could be even more significant and promising in neuroprotective approaches in NDs therapy (45).

Bioconjugates of curcumin such as di-demethylenated piperoyl, di-valinoyl and di-glutamoyl esters improve neuroprotective effects against nitrosative stress and mitochondrial dysfunction and damage (47). To compensate for the poor bioavailability of curcumin, curcumin encapsulated solid lipid nanoparticles (CSLNs) has been shown to significantly increase the activity of mitochondrial ETC complexes and cytochrome levels. Moreover, CSLNs also restore GSH levels and SOD activity. CSLNs markedly reduce the mitochondrial swelling, lipid peroxidation, protein carbonyls and ROS and also promote the Nrf2 antioxidant pathway (44). When encapsulated in nano-sized 
PLGA curcumin exerts its neuro- and mitochondrial-protective effects through the regulation of $\mathrm{NF}-\kappa \mathrm{B}$ (p65) and also reduce the caspase-9a expression as well as the apoptosis by ameliorating CSF levels of TNF- $\alpha$ and IL-1 $\beta$ (46).

\section{The Promise of Curcumin for NDs Therapy}

Curcumin has the potential to protect the CNS cells against a myriad of conditions including NDs. It has been shown that curcumin not only protect mitochondrial dysfunction and inhibit neuronal death by targeting wide-range of crucial pathways including oxidative stress/ROS/RNS, intrinsic/extrinsic pathway of apoptosis, neuroinflammatory mediators as well as microglial cells activation and other glial cells, but also attenuate the neuronal loss by many diseases/injuries and neurotoxic compounds. Many conditions such as hypertension, diabetes, atrial fibrillation, ischemic, heart-disease, dyslipidemia and obesity have the potential to induce stroke especially ischemic stroke, which increases the risk of dementia up to five-fold (128). It has been shown that curcumin can protect the CNS cell against ischemia-induced mitochondrial dysfunction and the onset of NDs.

Due to its structural properties, it has poor bioavailability however, there is an increasing number of studies using nano-/micro-sized and encapsulated form of curcumin to enhance its bioavailability. By developing hybrid medications with curcumin and other natural compounds can potentiate the properties of curcumin even more which could be assessed in future clinical trials. Hence the use of curcumin is a promising therapeutic strategy to cope with the growing trend of NDs.

\section{Conclusions}

Based on in vitro (Table 1) and in vivo (Table 2) evidence, curcumin has an excellent potential to protect CNS cells against mitochondria-related pathology in a wide variety of NDs and against several stimulating factors (e.g. ischemia-induced neurodegeneration via mitochondrial dysfunction), neurotoxic compounds (e.g. aluminum, manganese, MPP, HO, D-galactose, rotenone and t-BHP), lifestyle-induced neurodegeneration (e.g. heavy alcohol usage), excitotoxicity-induced neurodegeneration (e.g. L-glutamate) and adverse effects of some existing medications on neurodegeneration (e.g. oxaliplatin) as well as pathologies induced by misfolded/aggregated-/mutant proteins (e.g. A $\beta$, APP and $\alpha$-synuclein). Moreover, curcumin exerts its mitochondria protecting properties by: 1. retaining $\Delta \Psi \mathrm{m} /$ the activities of mitochondrial ETC complexes (48) and Bax/Bcl-2 ratio (52); 2. enhancing/increasing mitochondrial fusion activity, mitochondrial biogenesis and synaptic proteins (53); 3. reducing fission machinery (53), mitochondrial swelling, lipid peroxidation, protein carbonylation (44), levels of oxidized lipids (49) neuroinflammation (54), apoptosis (55-57), cytochrome c, caspase-3 and -9 activation, and mitochondrial depolarization (58); 4. modulating/targeting the phospho-CREB-BDNF signaling (54) and Nrf2 (59) and 5. restoring GSH levels and SOD (44). 
In conclusion, curcumin is associated with biological properties on mitochondrial dysfunction and its related abnormalities and could be a potential therapeutic candidate for the management of various NDs.

Conflict of interests: None.

Funding: None. 


\section{References}

[1] A. Hesari, M. Azizian, A. Sheikhi, A. Nesaei, S. Sanaei, N. Mahinparvar, M. Derakhshani, P. Hedayt, F. Ghasemi, H. Mirzaei (2019) Chemopreventive and therapeutic potential of curcumin in esophageal cancer: Current and future status. International journal of cancer 144:1215-1226.

[2] A. Hesari, M. Rezaei, M. Rezaei, M. Dashtiahangar, M. Fathi, J. G. Rad, F. Momeni, A. Avan, F. Ghasemi (2019) Effect of curcumin on glioblastoma cells. Journal of cellular physiology 234:10281-10288.

[3] A. A. Momtazi-Borojeni, F. Ghasemi, A. Hesari, M. Majeed, M. Caraglia, A. Sahebkar (2018) Anti-Cancer and Radio-Sensitizing Effects of Curcumin in Nasopharyngeal Carcinoma. Current pharmaceutical design 24:2121-2128.

[4] K. I. Priyadarsini (2014) The chemistry of curcumin: from extraction to therapeutic agent. Molecules (Basel, Switzerland) 19:20091-20112.

[5] E. Schraufstatter, H. Bernt (1949) Antibacterial action of curcumin and related compounds. Nature 164:456.

[6] K. I. Priyadarsini (2014) The chemistry of curcumin: from extraction to therapeutic agent. Molecules 19:20091-20112.

[7] Y. Panahi, N. Khalili, E. Sahebi, S. Namazi, M. S. Karimian, M. Majeed, A. Sahebkar (2017) Antioxidant effects of curcuminoids in patients with type 2 diabetes mellitus: a randomized controlled trial. Inflammopharmacology 25:25-31.

[8] M. Iranshahi, A. Sahebkar, M. Takasaki, T. Konoshima, H. Tokuda (2009) Cancer chemopreventive activity of the prenylated coumarin, umbelliprenin, in vivo. European Journal of Cancer Prevention 18:412-415.

[9] H. Mirzaei, A. Masoudifar, A. Sahebkar, N. Zare, J. S. Nahand, B. Rashidi, E. Mehrabian, M. Mohammadi, H. R. Mirzaei, M. R. Jaafari (2017) MicroRNA: A novel target of curcumin in cancer therapy. Journal of cellular physiology 233:3004-3015.

[10] M. Teymouri, M. Pirro, T. P. Johnston, A. Sahebkar (2017) Curcumin as a multifaceted compound against human papilloma virus infection and cervical cancers: A review of chemistry, cellular, molecular, and preclinical features. BioFactors 43:331-346.

[11] A. Sahebkar (2013) Why it is necessary to translate curcumin into clinical practice for the prevention and treatment of metabolic syndrome? BioFactors 39:197-208.

[12] Y. Panahi, N. Khalili, M. S. Hosseini, M. Abbasinazari, A. Sahebkar (2014) Lipid-modifying effects of adjunctive therapy with curcuminoids-piperine combination in patients with metabolic syndrome: Results of a randomized controlled trial. Complementary Therapies in Medicine 22:851-857.

[13] S. Rahmani, S. Asgary, G. Askari, M. Keshvari, M. Hatamipour, A. Feizi, A. Sahebkar (2016) Treatment of Non-alcoholic Fatty Liver Disease with Curcumin: A Randomized Placebo-controlled Trial. Phytotherapy research : PTR 30:1540-1548.

[14] Z. Narges Amel, P. Matteo, P. J. Thomas, S. Amirhossein (2017) Is There a Role for Curcumin Supplementation in the Treatment of Non-Alcoholic Fatty Liver Disease? The Data Suggest Yes. Current pharmaceutical design 23:969-982.

[15] V. Youreva, G. Kapakos, A. K. Srivastava (2013) Insulin-like growth-factor-1-induced PKB signaling and Egr-1 expression is inhibited by curcumin in A-10 vascular smooth muscle cells. Canadian journal of physiology and pharmacology 91:241-247.

[16] A. Saeidinia, F. Keihanian, A. E. Butler, R. K. Bagheri, S. L. Atkin, A. Sahebkar (2018) Curcumin in heart failure: A choice for complementary therapy? Pharmacological Research 131:112-119.

[17] D. Lelli, A. Sahebkar, T. P. Johnston, C. Pedone (2017) Curcumin use in pulmonary diseases: State of the art and future perspectives. Pharmacol Res 115:133-148. 
[18] Y. Panahi, P. Kianpour, R. Mohtashami, R. Jafari, L. E. Simental-Mendia, A. Sahebkar (2016) Curcumin Lowers Serum Lipids and Uric Acid in Subjects With Nonalcoholic Fatty Liver Disease: A Randomized Controlled Trial. Journal of cardiovascular pharmacology 68:223-229.

[19] F. Keihanian, A. Saeidinia, R. K. Bagheri, T. P. Johnston, A. Sahebkar (2018) Curcumin, hemostasis, thrombosis, and coagulation. Journal of cellular physiology 233:4497-4511.

[20] V. S. Yadav, K. P. Mishra, D. P. Singh, S. Mehrotra, V. K. Singh (2005) Immunomodulatory effects of curcumin. Immunopharmacology and immunotoxicology 27:485-497.

[21] E. Abdollahi, A. A. Momtazi, T. P. Johnston, A. Sahebkar (2018) Therapeutic effects of curcumin in inflammatory and immune-mediated diseases: A nature-made jack-of-all-trades? Journal of cellular physiology 233:830-848.

[22] N. Parsamanesh, M. Moossavi, A. Bahrami, A. E. Butler, A. Sahebkar (2018) Therapeutic potential of curcumin in diabetic complications. Pharmacol Res 136:181-193.

[23] A. Sahebkar, Y. Henrotin (2016) Analgesic Efficacy and Safety of Curcuminoids in Clinical Practice: A Systematic Review and Meta-Analysis of Randomized Controlled Trials. Pain medicine (Malden, Mass) 17:1192-1202.

[24] Y. Panahi, M. S. Hosseini, N. Khalili, E. Naimi, M. Majeed, A. Sahebkar (2015) Antioxidant and antiinflammatory effects of curcuminoid-piperine combination in subjects with metabolic syndrome: A randomized controlled trial and an updated meta-analysis. Clinical Nutrition 34:1101-1108.

[25] A. Sahebkar, A. F. G. Cicero, L. E. Simental-Mendía, B. B. Aggarwal, S. C. Gupta (2016) Curcumin downregulates human tumor necrosis factor- $\alpha$ levels: A systematic review and meta-analysis ofrandomized controlled trials. Pharmacological Research 107:234-242.

[26] M. Ghandadi, A. Sahebkar (2017) Curcumin: An Effective Inhibitor of Interleukin-6. Current pharmaceutical design 23:921-931.

[27] M. S. Karimian, M. Pirro, M. Majeed, A. Sahebkar (2017) Curcumin as a natural regulator of monocyte chemoattractant protein-1. Cytokine \& Growth Factor Reviews 33:55-63.

[28] K. I. Priyadarsini (2013) Chemical and structural features influencing the biological activity of curcumin. Current pharmaceutical design 19:2093-2100.

[29] Y. Panahi, A. Saadat, F. Beiraghdar, S. M. Hosseini Nouzari, H. R. Jalalian, A. Sahebkar (2014) Antioxidant effects of bioavailability-enhanced curcuminoids in patients with solid tumors: A randomized double-blind placebo-controlled trial. Journal of Functional Foods 6:615-622.

[30] M. Golpich, E. Amini, Z. Mohamed, R. Azman Ali, N. Mohamed Ibrahim, A. Ahmadiani (2017) Mitochondrial Dysfunction and Biogenesis in Neurodegenerative diseases: Pathogenesis and Treatment. CNS neuroscience \& therapeutics 23:5-22.

[31] M. G. Erkkinen, M. O. Kim, M. D. Geschwind (2018) Clinical Neurology and Epidemiology of the Major Neurodegenerative Diseases. Cold Spring Harbor perspectives in biology 10.

[32] K. R. Scott, A. M. Barrett (2007) Dementia syndromes: evaluation and treatment. Expert review of neurotherapeutics 7:407-422.

[33] B. N. Dugger, D. W. Dickson (2017) Pathology of Neurodegenerative Diseases. Cold Spring Harbor perspectives in biology 9.

[34] A. D. Gitler, P. Dhillon, J. Shorter (2017) Neurodegenerative disease: models, mechanisms, and a new hope. Disease Models \&amp; Mechanisms 10:499-502.

[35] F. Durães, M. Pinto, E. Sousa (2018) Old Drugs as New Treatments for Neurodegenerative Diseases. Pharmaceuticals (Basel, Switzerland) 11:44.

[36] G. D. Cuny (2012) Neurodegenerative diseases: challenges and opportunities. Future Medicinal Chemistry 4:1647-1649.

[37] P. Batista, A. Pereira (2016) Quality of Life in Patients with Neurodegenerative Diseases.

[38] A. Doble (1999) The Role of Excitotoxicity in Neurodegenerative Disease: Implications for Therapy. Pharmacology \& Therapeutics 81:163-221. 
[39] C. A. Ross, M. A. Poirier (2004) Protein aggregation and neurodegenerative disease. Nature medicine 10 Suppl:S10-17.

[40] B. Uttara, A. V. Singh, P. Zamboni, R. T. Mahajan (2009) Oxidative stress and neurodegenerative diseases: a review of upstream and downstream antioxidant therapeutic options. Current neuropharmacology 7:65-74.

[41] H. Fu, J. Hardy, K. E. Duff (2018) Selective vulnerability in neurodegenerative diseases. Nature neuroscience 21:1350-1358.

[42] S. Arun, L. Liu, G. Donmez (2016) Mitochondrial Biology and Neurological Diseases. Curr Neuropharmacol 14:143-154.

[43] S. Hagl, A. Kocher, C. Schiborr, N. Kolesova, J. Frank, G. P. Eckert (2015) Curcumin micelles improve mitochondrial function in neuronal PC12 cells and brains of NMRI mice - Impact on bioavailability. Neurochemistry international 89:234-242.

[44] R. Sandhir, A. Yadav, A. Mehrotra, A. Sunkaria, A. Singh, S. Sharma (2014) Curcumin nanoparticles attenuate neurochemical and neurobehavioral deficits in experimental model of Huntington's disease. Neuromolecular medicine 16:106-118.

[45] J. E. Chojnacki, K. Liu, X. Yan, S. Toldo, T. Selden, M. Estrada, M. I. Rodríguez-Franco, M. S. Halquist, D. Ye, S. Zhang (2014) Discovery of 5-(4-hydroxyphenyl)-3-oxo-pentanoic acid [2-(5-methoxy-1Hindol-3-yl)-ethyl]-amide as a neuroprotectant for Alzheimer's disease by hybridization of curcumin and melatonin. ACS chemical neuroscience 5:690-699.

[46] C. Z. Chang, S. C. Wu, C. L. Lin, A. L. Kwan (2015) Curcumin, encapsulated in nano-sized PLGA, downregulates nuclear factor kappaB (p65) and subarachnoid hemorrhage induced early brain injury in a rat model. Brain research 1608:215-224.

[47] R. B. Mythri, G. Harish, S. K. Dubey, K. Misra, M. M. Bharath (2011) Glutamoyl diester of the dietary polyphenol curcumin offers improved protection against peroxynitrite-mediated nitrosative stress and damage of brain mitochondria in vitro: implications for Parkinson's disease. Molecular and cellular biochemistry 347:135-143.

[48] R. L. Jayaraj, K. Tamilselvam, T. Manivasagam, N. Elangovan (2013) Neuroprotective effect of CNB001, a novel pyrazole derivative of curcumin on biochemical and apoptotic markers against rotenone-induced SK-N-SH cellular model of Parkinson's disease. Journal of molecular neuroscience : $\mathrm{MN}$ 51:863-870.

[49] O. J. Banji, D. Banji, K. Ch (2014) Curcumin and hesperidin improve cognition by suppressing mitochondrial dysfunction and apoptosis induced by D-galactose in rat brain. Food and chemical toxicology : an international journal published for the British Industrial Biological Research Association 74:51-59.

[50] K. I. Priyadarsini (1997) Free radical reactions of curcumin in membrane models. Free radical biology \& medicine 23:838-843.

[51] B. Mishra, K. I. Priyadarsini, M. K. Bhide, R. M. Kadam, H. Mohan (2004) Reactions of superoxide radicals with curcumin: probable mechanisms by optical spectroscopy and EPR. Free radical research 38:355-362.

[52] Z. J. Liu, H. Q. Liu, C. Xiao, H. Z. Fan, Q. Huang, Y. H. Liu, Y. Wang (2014) Curcumin protects neurons against oxygen-glucose deprivation/reoxygenation-induced injury through activation of peroxisome proliferator-activated receptor-gamma function. Journal of neuroscience research 92:1549-1559.

[53] P. H. Reddy, M. Manczak, X. Yin, M. C. Grady, A. Mitchell, R. Kandimalla, C. S. Kuruva (2016) Protective effects of a natural product, curcumin, against amyloid beta induced mitochondrial and synaptic toxicities in Alzheimer's disease. Journal of investigative medicine : the official publication of the American Federation for Clinical Research 64:1220-1234. 
[54] M. Motaghinejad, M. Motevalian, S. Fatima, H. Hashemi, M. Gholami (2017) Curcumin confers neuroprotection against alcohol-induced hippocampal neurodegeneration via CREB-BDNF pathway in rats. Biomedicine $\&$ pharmacotherapy = Biomedecine $\&$ pharmacotherapie 87:721740.

[55] Q. Wang, A. Y. Sun, A. Simonyi, M. D. Jensen, P. B. Shelat, G. E. Rottinghaus, R. S. MacDonald, D. K. Miller, D. E. Lubahn, G. A. Weisman, G. Y. Sun (2005) Neuroprotective mechanisms of curcumin against cerebral ischemia-induced neuronal apoptosis and behavioral deficits. Journal of neuroscience research 82:138-148.

[56] J. Chen, X. Q. Tang, J. L. Zhi, Y. Cui, H. M. Yu, E. H. Tang, S. N. Sun, J. Q. Feng, P. X. Chen (2006) Curcumin protects PC12 cells against 1-methyl-4-phenylpyridinium ion-induced apoptosis by bcl-2mitochondria-ROS-iNOS pathway. Apoptosis : an international journal on programmed cell death 11:943-953.

[57] E. Park, H. S. Chun (2017) Protective Effects of Curcumin on Manganese-Induced BV-2 Microglial Cell Death. Biological \& pharmaceutical bulletin 40:1275-1281.

[58] Z. Liu, Y. Yu, X. Li, C. A. Ross, W. W. Smith (2011) Curcumin protects against A53T alpha-synucleininduced toxicity in a PC12 inducible cell model for Parkinsonism. Pharmacol Res 63:439-444.

[59] L. Liao, J. Shi, C. Jiang, L. Zhang, L. Feng, J. Liu, J. Zhang (2019) Activation of anti-oxidant of curcumin pyrazole derivatives through preservation of mitochondria function and Nrf2 signaling pathway. Neurochemistry international 125:82-90.

[60] M. R. de Oliveira, F. R. Jardim, W. N. Setzer, S. M. Nabavi, S. F. Nabavi (2016) Curcumin, mitochondrial biogenesis, and mitophagy: Exploring recent data and indicating future needs. Biotechnol Adv 34:813-826.

[61] Y. Mizuno (2014) Recent Research Progress in and Future Perspective on Treatment of Parkinson's Disease. Integrative Medicine International 1:67-79.

[62] R. S. Doody, S. H. Ferris, S. Salloway, Y. Sun, R. Goldman, W. E. Watkins, Y. Xu, A. K. Murthy (2009) Donepezil treatment of patients with $\mathrm{MCl}$ : a 48-week randomized, placebo-controlled trial. Neurology 72:1555-1561.

[63] R. R. Tampi, D. J. Tampi, S. Balachandran, S. Srinivasan (2016) Antipsychotic use in dementia: a systematic review of benefits and risks from meta-analyses. Therapeutic advances in chronic disease 7:229-245.

[64] X. Chen, W. Pan (2014) The Treatment Strategies for Neurodegenerative Diseases by Integrative Medicine. Integrative Medicine International 1:223-225.

[65] M. S. Okun (2014) Deep-brain stimulation--entering the era of human neural-network modulation. The New England journal of medicine 371:1369-1373.

[66] Z. Stozicka, N. Zilka, P. Novak, B. Kovacech, O. Bugos, M. Novak (2010) Genetic background modifies neurodegeneration and neuroinflammation driven by misfolded human tau protein in rat model of tauopathy: implication for immunomodulatory approach to Alzheimer's disease. Journal of Neuroinflammation 7:64.

[67] M. Chin-Chan, J. Navarro-Yepes, B. Quintanilla-Vega (2015) Environmental pollutants as risk factors for neurodegenerative disorders: Alzheimer and Parkinson diseases. Frontiers in cellular neuroscience 9:124.

[68] M. T. Heneka, M. J. Carson, J. El Khoury, G. E. Landreth, F. Brosseron, D. L. Feinstein, A. H. Jacobs, T. Wyss-Coray, J. Vitorica, R. M. Ransohoff, K. Herrup, S. A. Frautschy, B. Finsen, G. C. Brown, A. Verkhratsky, K. Yamanaka, J. Koistinaho, E. Latz, A. Halle, G. C. Petzold, T. Town, D. Morgan, M. L. Shinohara, V. H. Perry, C. Holmes, N. G. Bazan, D. J. Brooks, S. Hunot, B. Joseph, N. Deigendesch, O. Garaschuk, E. Boddeke, C. A. Dinarello, J. C. Breitner, G. M. Cole, D. T. Golenbock, M. P. Kummer (2015) Neuroinflammation in Alzheimer's disease. The Lancet Neurology 14:388-405. 
[69] C. Patterson (2018) World Alzheimer Report 2018-The state of the art of dementia research: New frontiers. Alzheimer's Disease International (ADI): London, UK.

[70] E. R. Dorsey, A. Elbaz, E. Nichols, F. Abd-Allah, A. Abdelalim, J. C. Adsuar, M. G. Ansha, C. Brayne, J.-Y. J. Choi, D. Collado-Mateo, N. Dahodwala, H. P. Do, D. Edessa, M. Endres, S.-M. Fereshtehnejad, K. J. Foreman, F. G. Gankpe, R. Gupta, G. J. Hankey, S. I. Hay, M. I. Hegazy, D. T. Hibstu, A. Kasaeian, Y. Khader, I. Khalil, Y.-H. Khang, Y. J. Kim, Y. Kokubo, G. Logroscino, J. Massano, N. Mohamed Ibrahim, M. A. Mohammed, A. Mohammadi, M. Moradi-Lakeh, M. Naghavi, B. T. Nguyen, Y. L. Nirayo, F. A. Ogbo, M. O. Owolabi, D. M. Pereira, M. J. Postma, M. Qorbani, M. A. Rahman, K. T. Roba, H. Safari, S. Safiri, M. Satpathy, M. Sawhney, A. Shafieesabet, M. S. Shiferaw, M. Smith, C. E. I. Szoeke, R. Tabarés-Seisdedos, N. T. Truong, K. N. Ukwaja, N. Venketasubramanian, S. Villafaina, K. g. weldegwergs, R. Westerman, T. Wijeratne, A. S. Winkler, B. T. Xuan, N. Yonemoto, V. L. Feigin, T. Vos, C. J. L. Murray (2018) Global, regional, and national burden of Parkinson's disease, 1990\&\#x2013;2016: a systematic analysis for the Global Burden of Disease Study 2016. The Lancet Neurology 17:939-953.

[71] T. Vlaar, S. Kab, Y. Schwaab, N. Frery, A. Elbaz, F. Moisan (2018) Association of Parkinson's disease with industry sectors: a French nationwide incidence study. European journal of epidemiology 33:1101-1111.

[72] G. Pezzoli, E. Cereda (2013) Exposure to pesticides or solvents and risk of Parkinson disease. Neurology 80:2035-2041.

[73] A. Verstraeten, J. Theuns, C. Van Broeckhoven (2015) Progress in unraveling the genetic etiology of Parkinson disease in a genomic era. Trends in Genetics 31:140-149.

[74] I. G. McKeith, B. F. Boeve, D. W. Dickson, G. Halliday, J.-P. Taylor, D. Weintraub, D. Aarsland, J. Galvin, J. Attems, C. G. Ballard, A. Bayston, T. G. Beach, F. Blanc, N. Bohnen, L. Bonanni, J. Bras, P. Brundin, D. Burn, A. Chen-Plotkin, J. E. Duda, O. El-Agnaf, H. Feldman, T. J. Ferman, D. Ffytche, H. Fujishiro, D. Galasko, J. G. Goldman, S. N. Gomperts, N. R. Graff-Radford, L. S. Honig, A. Iranzo, K. Kantarci, D. Kaufer, W. Kukull, V. M. Y. Lee, J. B. Leverenz, S. Lewis, C. Lippa, A. Lunde, M. Masellis, E. Masliah, P. McLean, B. Mollenhauer, T. J. Montine, E. Moreno, E. Mori, M. Murray, J. T. O'Brien, S. Orimo, R. B. Postuma, S. Ramaswamy, O. A. Ross, D. P. Salmon, A. Singleton, A. Taylor, A. Thomas, P. Tiraboschi, J. B. Toledo, J. Q. Trojanowski, D. Tsuang, Z. Walker, M. Yamada, K. Kosaka (2017) Diagnosis and management of dementia with Lewy bodies: Fourth consensus report of the DLB Consortium. Neurology 89:88-100.

[75] (1993) A novel gene containing a trinucleotide repeat that is expanded and unstable on Huntington's disease chromosomes. The Huntington's Disease Collaborative Research Group. Cell 72:971-983.

[76] R. A. C. Roos (2010) Huntington's disease: a clinical review. Orphanet journal of rare diseases 5:4040.

[77] S. B. Prusiner (1991) Molecular biology of prion diseases. Science 252:1515-1522.

[78] L. P. Rowland, N. A. Shneider (2001) Amyotrophic lateral sclerosis. The New England journal of medicine 344:1688-1700.

[79] S. Zarei, K. Carr, L. Reiley, K. Diaz, O. Guerra, P. F. Altamirano, W. Pagani, D. Lodin, G. Orozco, A. Chinea (2015) A comprehensive review of amyotrophic lateral sclerosis. Surgical neurology international 6:171-171.

[80] Julia J. Harris, R. Jolivet, D. Attwell (2012) Synaptic Energy Use and Supply. Neuron 75:762-777.

[81] V. G. Antico Arciuch, M. E. Elguero, J. J. Poderoso, M. C. Carreras (2012) Mitochondrial regulation of cell cycle and proliferation. Antioxidants \& redox signaling 16:1150-1180.

[82] S. W. G. Tait, D. R. Green (2012) Mitochondria and cell signalling. Journal of Cell Science 125:807-815.

[83] B. Su, Y. S. Ji, X. L. Sun, X. H. Liu, Z. Y. Chen (2014) Brain-derived neurotrophic factor (BDNF)-induced mitochondrial motility arrest and presynaptic docking contribute to BDNF-enhanced synaptic transmission. The Journal of biological chemistry 289:1213-1226. 
[84] D. De Rasmo, A. Signorile, E. Roca, S. Papa (2009) cAMP response element-binding protein (CREB) is imported into mitochondria and promotes protein synthesis. The FEBS journal 276:4325-4333.

[85] K. Sakamoto, K. Karelina, K. Obrietan (2011) CREB: a multifaceted regulator of neuronal plasticity and protection. J Neurochem 116:1-9.

[86] X. J. Chen, R. A. Butow (2005) The organization and inheritance of the mitochondrial genome. Nature reviews Genetics 6:815-825.

[87] J. R. Richardson, W. M. Caudle, T. S. Guillot, J. L. Watson, E. Nakamaru-Ogiso, B. B. Seo, T. B. Sherer, J. T. Greenamyre, T. Yagi, A. Matsuno-Yagi, G. W. Miller (2006) Obligatory Role for Complex I Inhibition in the Dopaminergic Neurotoxicity of 1-Methyl-4-phenyl-1,2,3,6-tetrahydropyridine (MPTP). Toxicological Sciences 95:196-204.

[88] T. Kitada, S. Asakawa, N. Hattori, H. Matsumine, Y. Yamamura, S. Minoshima, M. Yokochi, Y. Mizuno, N. Shimizu (1998) Mutations in the parkin gene cause autosomal recessive juvenile parkinsonism. Nature 392:605-608.

[89] E. M. Valente, P. M. Abou-Sleiman, V. Caputo, M. M. Muqit, K. Harvey, S. Gispert, Z. Ali, D. Del Turco, A. R. Bentivoglio, D. G. Healy, A. Albanese, R. Nussbaum, R. Gonzalez-Maldonado, T. Deller, S. Salvi, P. Cortelli, W. P. Gilks, D. S. Latchman, R. J. Harvey, B. Dallapiccola, G. Auburger, N. W. Wood (2004) Hereditary early-onset Parkinson's disease caused by mutations in PINK1. Science 304:1158-1160.

[90] M. Funayama, K. Hasegawa, H. Kowa, M. Saito, S. Tsuji, F. Obata (2002) A new locus for Parkinson's disease (PARK8) maps to chromosome 12p11.2-q13.1. Annals of neurology 51:296-301.

[91] H. M. Lanoiselee, G. Nicolas, D. Wallon, A. Rovelet-Lecrux, M. Lacour, S. Rousseau, A. C. Richard, F. Pasquier, A. Rollin-Sillaire, O. Martinaud, M. Quillard-Muraine, V. de la Sayette, C. BoutoleauBretonniere, F. Etcharry-Bouyx, V. Chauvire, M. Sarazin, I. le Ber, S. Epelbaum, T. Jonveaux, O. Rouaud, M. Ceccaldi, O. Felician, O. Godefroy, M. Formaglio, B. Croisile, S. Auriacombe, L. Chamard, J. L. Vincent, M. Sauvee, C. Marelli-Tosi, A. Gabelle, C. Ozsancak, J. Pariente, C. Paquet, D. Hannequin, D. Campion (2017) APP, PSEN1, and PSEN2 mutations in early-onset Alzheimer disease: A genetic screening study of familial and sporadic cases. PLoS medicine 14:e1002270.

[92] S. Sarasija, J. T. Laboy, Z. Ashkavand, J. Bonner, Y. Tang, K. R. Norman (2018) Presenilin mutations deregulate mitochondrial $\mathrm{Ca} 2+$ homeostasis and metabolic activity causing neurodegeneration in Caenorhabditis elegans. elife 7:e33052.

[93] M. I. G. Lopez Sanchez, H. S. Waugh, A. Tsatsanis, B. X. Wong, J. G. Crowston, J. A. Duce, I. A. Trounce (2017) Amyloid precursor protein drives down-regulation of mitochondrial oxidative phosphorylation independent of amyloid beta. Sci Rep 7:9835-9835.

[94] O. Sunday, M. Adekunle, O. Temitope, A. Richard, A. Samuel, A. Olufunminyi, O. Elizabeth (2014) Alteration in antioxidants level and lipid peroxidation of patients with neurodegenerative diseases \{Alzheimer's disease and Parkinson disease\}. International Journal of Nutrition, Pharmacology, Neurological Diseases 4:146-152.

[95] B. I. Frohnert, D. A. Bernlohr (2013) Protein carbonylation, mitochondrial dysfunction, and insulin resistance. Adv Nutr 4:157-163.

[96] R. Sultana, M. Perluigi, D. A. Butterfield (2013) Lipid peroxidation triggers neurodegeneration: a redox proteomics view into the Alzheimer disease brain. Free radical biology \& medicine 62:157-169.

[97] J. D. Hayes, A. T. Dinkova-Kostova (2014) The Nrf2 regulatory network provides an interface between redox and intermediary metabolism. Trends in biochemical sciences 39:199-218.

[98] K. M. Holmström, R. V. Kostov, A. T. Dinkova-Kostova (2016) The multifaceted role of Nrf2 in mitochondrial function. Curr Opin Toxicol 1:80-91.

[99] L. D. Zorova, V. A. Popkov, E. Y. Plotnikov, D. N. Silachev, I. B. Pevzner, S. S. Jankauskas, V. A. Babenko, S. D. Zorov, A. V. Balakireva, M. Juhaszova, S. J. Sollott, D. B. Zorov (2018) Mitochondrial membrane potential. Analytical biochemistry 552:50-59. 
[100] N. Zamzami, P. Marchetti, M. Castedo, D. Decaudin, A. Macho, T. Hirsch, S. A. Susin, P. X. Petit, B. Mignotte, G. Kroemer (1995) Sequential reduction of mitochondrial transmembrane potential and generation of reactive oxygen species in early programmed cell death. The Journal of experimental medicine 182:367-377.

[101] J. Lee, J. H. Boo, H. Ryu (2009) The failure of mitochondria leads to neurodegeneration: Do mitochondria need a jump start? Advanced drug delivery reviews 61:1316-1323.

[102] E. Szegezdi, S. E. Logue, A. M. Gorman, A. Samali (2006) Mediators of endoplasmic reticulum stressinduced apoptosis. EMBO Rep 7:880-885.

[103] S. Elmore (2007) Apoptosis: a review of programmed cell death. Toxicologic pathology 35:495-516.

[104] J. Rose, C. Brian, J. Woods, A. Pappa, M. I. Panayiotidis, R. Powers, R. Franco (2017) Mitochondrial dysfunction in glial cells: Implications for neuronal homeostasis and survival. Toxicology 391:109115.

[105] D. R. Green, F. Llambi (2015) Cell Death Signaling. Cold Spring Harbor perspectives in biology 7.

[106] D. V. Hansen, J. E. Hanson, M. Sheng (2018) Microglia in Alzheimer's disease. The Journal of Cell Biology 217:459.

[107] C. Bate, S. Kempster, V. Last, A. Williams (2006) Interferon-gamma increases neuronal death in response to amyloid-beta1-42. J Neuroinflammation 3:7.

[108] J. Guadagno, X. Xu, M. Karajgikar, A. Brown, S. P. Cregan (2013) Microglia-derived TNFa induces apoptosis in neural precursor cells via transcriptional activation of the $\mathrm{Bcl}-2$ family member Puma. Cell Death \&Amp; Disease 4:e538.

[109] A. Y. Abramov, L. Canevari, M. R. Duchen (2003) Changes in Intracellular Calcium and Glutathione in Astrocytes as the Primary Mechanism of Amyloid Neurotoxicity. The Journal of Neuroscience 23:5088.

[110] M. Comporti, C. Signorini, S. Leoncini, C. Gardi, L. Ciccoli, A. Giardini, D. Vecchio, B. Arezzini (2010) Ethanol-induced oxidative stress: basic knowledge. Genes \& Nutrition 5:101-109.

[111] S. A. Morris, D. W. Eaves, A. R. Smith, K. Nixon (2010) Alcohol inhibition of neurogenesis: a mechanism of hippocampal neurodegeneration in an adolescent alcohol abuse model. Hippocampus 20:596-607.

[112] L. Jing, C.-m. Jin, S.-s. Li, F.-m. Zhang, L. Yuan, W.-m. Li, Y. Sang, S. Li, L.-j. Zhou (2012) Chronic alcohol intake-induced oxidative stress and apoptosis: role of CYP2E1 and calpain-1 in alcoholic cardiomyopathy. Molecular and cellular biochemistry 359:283-292.

[113] B. H. Ali (2010) Amelioration of oxaliplatin neurotoxicity by drugs in humans and experimental animals: a minireview of recent literature. Basic \& clinical pharmacology \& toxicology 106:272279.

[114] M. Waseem, S. Parvez (2016) Neuroprotective activities of curcumin and quercetin with potential relevance to mitochondrial dysfunction induced by oxaliplatin. Protoplasma 253:417-430.

[115] Y. G. Zhu, X. C. Chen, Z. Z. Chen, Y. Q. Zeng, G. B. Shi, Y. H. Su, X. Peng (2004) Curcumin protects mitochondria from oxidative damage and attenuates apoptosis in cortical neurons. Acta pharmacologica Sinica 25:1606-1612.

[116] P. H. Reddy, M. F. Beal (2008) Amyloid beta, mitochondrial dysfunction and synaptic damage: implications for cognitive decline in aging and Alzheimer's disease. Trends Mol Med 14:45-53.

[117] X. Zhang, D. Jones, F. Gonzalez-Lima (2006) Neurodegeneration produced by rotenone in the mouse retina: a potential model to investigate environmental pesticide contributions to neurodegenerative diseases. Journal of toxicology and environmental health Part A 69:16811697.

[118] D. K. Khatri, A. R. Juvekar (2016) Neuroprotective effect of curcumin as evinced by abrogation of rotenone-induced motor deficits, oxidative and mitochondrial dysfunctions in mouse model of Parkinson's disease. Pharmacology, biochemistry, and behavior 150-151:39-47. 
[119] J. Long, X. Wang, H. Gao, Z. Liu, C. Liu, M. Miao, X. Cui, L. Packer, J. Liu (2007) d-Galactose toxicity in mice is associated with mitochondrial dysfunction: protecting effects of mitochondrial nutrient $R$ alpha-lipoic acid. Biogerontology 8:373-381.

[120] H. I. Hurtig, J. Q. Trojanowski, J. Galvin, D. Ewbank, M. L. Schmidt, V. M. Y. Lee, C. M. Clark, G. Glosser, M. B. Stern, S. M. Gollomp, S. E. Arnold (2000) Alpha-synuclein cortical Lewy bodies correlate with dementia in Parkinson's disease. Neurology 54:1916.

[121] W. S. Kim, K. Kågedal, G. M. Halliday (2014) Alpha-synuclein biology in Lewy body diseases. Alzheimer's Research \& Therapy 6:73.

[122] A. C. Uğuz, A. Öz, M. Nazıroğlu (2016) Curcumin inhibits apoptosis by regulating intracellular calcium release, reactive oxygen species and mitochondrial depolarization levels in SH-SY5Y neuronal cells. Journal of Receptors and Signal Transduction 36:395-401.

[123] S. Przedborski, M. Vila (2001) MPTP: a review of its mechanisms of neurotoxicity. Clinical Neuroscience Research 1:407-418.

[124] M. R. Hynd, H. L. Scott, P. R. Dodd (2004) Glutamate-mediated excitotoxicity and neurodegeneration in Alzheimer's disease. Neurochemistry international 45:583-595.

[125] C.-H. Chang, H.-X. Chen, G. Yü, C.-C. Peng, R. Y. Peng (2014) Curcumin-Protected PC12 Cells Against Glutamate-Induced Oxidative Toxicity. Food technology and biotechnology 52:468-478.

[126] P. K. Sood, U. Nahar, B. Nehru (2011) Curcumin attenuates aluminum-induced oxidative stress and mitochondrial dysfunction in rat brain. Neurotoxicity research 20:351-361.

[127] H. Jiang, X. Tian, Y. Guo, W. Duan, H. Bu, C. Li (2011) Activation of Nuclear Factor Erythroid 2-Related Factor 2 Cytoprotective Signaling by Curcumin Protect Primary Spinal Cord Astrocytes against Oxidative Toxicity. Biological and Pharmaceutical Bulletin 34:1194-1197.

[128] R. N. Kalaria (2012) Risk factors and neurodegenerative mechanisms in stroke related dementia. Panminerva medica 54:139-148.

[129] A. Daverey, S. K. Agrawal (2016) Curcumin alleviates oxidative stress and mitochondrial dysfunction in astrocytes. Neuroscience 333:92-103.

[130] C. van der Merwe, H. C. van Dyk, L. Engelbrecht, F. H. van der Westhuizen, C. Kinnear, B. Loos, S. Bardien (2017) Curcumin Rescues a PINK1 Knock Down SH-SY5Y Cellular Model of Parkinson's Disease from Mitochondrial Dysfunction and Cell Death. Molecular neurobiology 54:2752-2762.

[131] H. Atamna, K. Boyle (2006) Amyloid-beta peptide binds with heme to form a peroxidase: relationship to the cytopathologies of Alzheimer's disease. Proceedings of the National Academy of Sciences of the United States of America 103:3381-3386.

[132] G. P. Eckert, C. Schiborr, S. Hagl, R. Abdel-Kader, W. E. Muller, G. Rimbach, J. Frank (2013) Curcumin prevents mitochondrial dysfunction in the brain of the senescence-accelerated mouse-prone 8. Neurochemistry international 62:595-602.

[133] J. S. Seo, Y. H. Leem, K. W. Lee, S. W. Kim, J. K. Lee, P. L. Han (2010) Severe motor neuron degeneration in the spinal cord of the Tg2576 mouse model of Alzheimer disease. Journal of Alzheimer's disease : JAD 21:263-276.

[134] Y. Zhang, Y. Yan, Y. Cao, Y. Yang, Q. Zhao, R. Jing, J. Hu, J. Bao (2017) Potential therapeutic and protective effect of curcumin against stroke in the male albino stroke-induced model rats. Life sciences 183:45-49. 


\section{Figure legends}

Figure 1. Genetic alterations (e.g. mutations) and environmental/external factors as well as their synergistic effects can induce the formation of reactive oxygen species (ROS), reactive nitrogen species (RNS) and other neurotoxic compounds, leading to accumulated/misfolded proteins and subsequent mitochondrial dysfunction. Mitochondrial dysfunction can contribute to neurodegeneration through several mechanisms including interference with cell signaling, redox state, microglial activation and lipid peroxidation. Curcumin can mitigate the destructive effects of ROS, RNS and other neurotoxic compounds by several mechanisms that result in blunted neurodegeneration. GSH: reduced glutathione, SOD: superoxide dismutase, ETC: electron transport chain. 
Table 1. Effects of Curcumin on Mitochondria Function on NDs in vitro.

\begin{tabular}{|c|c|c|c|c|c|}
\hline Author & $\begin{array}{l}\text { Species and cell } \\
\text { type }\end{array}$ & Agents & Dose & In vitro effects & Refs. \\
\hline $\begin{array}{l}\text { Liao et al. } \\
(2019)\end{array}$ & PC12 cells & $\begin{array}{l}\text { Six curcumin } \\
\text { pyrazole } \\
\text { derivatives }\end{array}$ & $\begin{array}{l}\text { Dose- and } \\
\text { time- } \\
\text { dependent } \\
\text { manner }\end{array}$ & $\begin{array}{l}\text { Curcumin pyrazole derivatives } \\
\text { potentially reduce ROS levels } \\
\text { and protect the neurons by } \\
\text { targeting and/or protecting } \\
\text { mitochondria and nrf2 signaling } \\
\text { pathway. }\end{array}$ & (59) \\
\hline $\begin{array}{l}\text { Daverey et al. } \\
\text { (2016) }\end{array}$ & $\begin{array}{l}\text { A172 (human } \\
\text { glioblastoma cell } \\
\text { line) and HA-sp } \\
\text { (human astrocytes } \\
\text { cell line derived } \\
\text { from the spinal } \\
\text { cord) astrocytes. }\end{array}$ & Curcumin & $\begin{array}{l}\text { Dose- and } \\
\text { time- } \\
\text { dependent } \\
\text { manner }\end{array}$ & $\begin{array}{l}\text { Curcumin not only protected } \\
\text { astrocytes from } \mathrm{H}_{2} \mathrm{O}_{2} \text {-induced } \\
\text { oxidative stress but also } \\
\text { reversed the mitochondrial } \\
\text { damage and dysfunction } \\
\text { induced by oxidative stress. }\end{array}$ & (129) \\
\hline \begin{tabular}{l}
\multicolumn{2}{l}{ Cihangir } \\
Uguz et al. \\
$(2015)$
\end{tabular} & SH-SY5Y cells & $\begin{array}{l}\text { Curcumin and } \\
\mathrm{H}_{2} \mathrm{O}_{2}\end{array}$ & $\begin{array}{lr}5 & \mathrm{mM} \\
\text { curcumin and } \\
100 \quad \mathrm{mM} \\
\mathrm{H}_{2} \mathrm{O}_{2}\end{array}$ & $\begin{array}{l}\text { Curcumin effectively induced } \\
\text { modulator effects on oxidative } \\
\text { stress and the levels of } \\
\text { intracellular } \mathrm{Ca}^{2+} \text {, caspase- } 3 \text { and } \\
-9 \text {. }\end{array}$ & (122) \\
\hline $\begin{array}{l}\text { Hagl et al. } \\
(2015)\end{array}$ & PC12 cells & $\begin{array}{l}\text { Curcumin } \\
\text { micelles }\end{array}$ & $\begin{array}{l}0.1 \mu \mathrm{M} \text { and } \\
10 \mu \mathrm{M}\end{array}$ & $\begin{array}{l}\text { Curcumin micelles prevented } \\
\text { mitochondria from swelling and } \\
\text { was a suitable substance for the } \\
\text { prevention of mitochondrial } \\
\text { dysfunction and } \\
\text { neurodegeneration. }\end{array}$ & (43) \\
\hline $\begin{array}{l}\text { Liu et al. } \\
(2011)\end{array}$ & $\begin{array}{l}\text { PC12 cells } \\
\text { expressing } \\
\text { inducible A53T } \alpha \text { - } \\
\text { synuclein }\end{array}$ & Curcumin & $\begin{array}{l}\text { Dose- } \\
\text { dependent } \\
\text { manner }\end{array}$ & $\begin{array}{l}\text { Curcumin reduced mutant } \alpha \text { - } \\
\text { synuclein-induced intracellular } \\
\text { reactive oxygen species (ROS) } \\
\text { levels, mitochondrial } \\
\text { depolarization, cytochrome c } \\
\text { release, and caspase-9 and } \\
\text { caspase-3 activation. }\end{array}$ & (58) \\
\hline $\begin{array}{l}\text { Chen et al. } \\
(2006)\end{array}$ & PC12 cells & Curcumin & $\begin{array}{l}\text { Dose- } \\
\text { dependent } \\
\text { manner }\end{array}$ & $\begin{array}{l}\text { Curcumin protected PC12 cells } \\
\text { against MPP+-induced } \\
\text { cytotoxicity and apoptosis by } \\
\text { inducing overexpression of Bcl- } \\
2 \text {, and reducing the loss of } \\
\text { mitochondrial membrane } \\
\text { potential, intracellular ROS and } \\
\text { overexpression of iNOS. }\end{array}$ & (56) \\
\hline $\begin{array}{l}\text { van der } \\
\text { Merwe et al. } \\
(2017)\end{array}$ & $\begin{array}{lr}\text { PINK1 } & \text { Knock } \\
\text { Down } & \text { SH-SY5Y } \\
\text { cell line } & \end{array}$ & Curcumin & $\begin{array}{l}\text { Dose- and } \\
\text { time- } \\
\text { dependent } \\
\text { manner }\end{array}$ & $\begin{array}{l}\text { This study demonstrated that } \\
\text { down regulation of PINK1 by } \\
\text { specific siRNA resulted in } \\
\text { features of mitochondrial } \\
\text { dysfunction and increased cell }\end{array}$ & (130) \\
\hline
\end{tabular}




\begin{tabular}{|c|c|c|c|c|c|}
\hline & & & & $\begin{array}{l}\text { death which were rescued and } \\
\text { reversed by curcumin. }\end{array}$ & \\
\hline $\begin{array}{l}\text { Chang et al. } \\
\text { (2014) }\end{array}$ & PC12 cells & $\begin{array}{l}\text { Curcumin and } \\
\text { glutamate }\end{array}$ & $\begin{array}{l}\text { Dose- and } \\
\text { time- } \\
\text { dependent } \\
\text { manner }\end{array}$ & $\begin{array}{l}\text { Curcumin effectively protected } \\
\text { PC12 cells against the } \\
\text { glutamate-induced oxidative } \\
\text { toxicity in two pathways: the } \\
\text { glutathione-dependent nitric } \\
\text { oxide-reactive oxygen species } \\
\text { pathway and the mitochondria- } \\
\text { dependent nitric oxide-reactive } \\
\text { oxygen species pathway. }\end{array}$ & (125) \\
\hline $\begin{array}{l}\text { Chojnacki et } \\
\text { al. (2014) }\end{array}$ & MC65 Cells & $\begin{array}{l}\text { hybrid } \\
\text { compounds of } \\
\text { curcumin and } \\
\text { melatonin } \\
\text { (named 7) }\end{array}$ & $\begin{array}{l}\text { Dose- } \\
\text { dependent } \\
\text { manner }\end{array}$ & $\begin{array}{l}\text { 7's antioxidant effects correlate } \\
\text { well with its neuroprotective } \\
\text { potency and these effects might } \\
\text { be due to its interference with } \\
\text { the interactions of amyloid- } \beta \\
\text { oligomers within the } \\
\text { mitochondria. }\end{array}$ & (45) \\
\hline $\begin{array}{l}\text { Mythri et al. } \\
\text { (2011) }\end{array}$ & N27 cells & $\begin{array}{l}\text { Bioconjugates } \\
\text { of curcumin } \\
\text { (Di- } \\
\text { demethylenated } \\
\text { piperoyl, di- } \\
\text { valinoyl and di- } \\
\text { glutamoyl } \\
\text { esters) }\end{array}$ & $\begin{array}{l}\text { Dose- } \\
\text { dependent } \\
\text { manner }\end{array}$ & $\begin{array}{l}\text { Glutamoyl diester of curcumin } \\
\text { showed the improved protection } \\
\text { against peroxynitrite-dependent } \\
\text { CI inhibition and protein } \\
\text { nitration. Additionally, Di- } \\
\text { glutamoyl curcumin protected } \\
\text { dopaminergic neurons against } \\
\mathrm{MPP}^{+} \text {-mediated neuronal death. }\end{array}$ & (47) \\
\hline $\begin{array}{l}\text { Jayaraj et al. } \\
\text { (2013) }\end{array}$ & SK-N-SH cells & $\begin{array}{l}\text { CNB-001 and } \\
\text { rotenone }\end{array}$ & $\begin{array}{lr}2 & \mu \mathrm{M} \\
\text { curcumin and } \\
100 \quad \mathrm{nM} \\
\text { rotenone } & \end{array}$ & $\begin{array}{l}\text { CNB-001 demonstrated } \\
\text { protection against rotenone- } \\
\text { induced toxicity by inhibiting } \\
\text { mitochondrial ROS generation, } \\
\text { retains } \Delta \Psi \mathrm{m} \text {, and prevents } \\
\text { apoptosis. Moreover, CNB-001 } \\
\text { offered neuroprotection by its } \\
\text { antioxidant, mitochondrial } \\
\text { protective, and antiapoptotic } \\
\text { properties. }\end{array}$ & (48) \\
\hline $\begin{array}{l}\text { Reddy et al. } \\
\text { (2016) }\end{array}$ & SH-SY5Y cells & $\begin{array}{l}\text { Curcumin and } \\
\mathrm{A} \beta\end{array}$ & $\begin{array}{l}\text { Dose- } \\
\text { dependent } \\
\text { manner }\end{array}$ & $\begin{array}{l}\text { After A } \beta \text { affections on } \\
\text { mitochondria, curcumin } \\
\text { enhanced mitochondrial fusion } \\
\text { activity, reduced fission } \\
\text { machinery, increased biogenesis } \\
\text { and synaptic proteins. }\end{array}$ & (53) \\
\hline $\begin{array}{l}\text { Park et al. } \\
(2017)\end{array}$ & $\begin{array}{l}\text { BV-2 Microglial } \\
\text { Cells }\end{array}$ & $\begin{array}{l}\text { Curcumin and } \\
\text { manganese }\end{array}$ & $\begin{array}{lr}0.1-10 \mu \mathrm{M} \\
\text { curcumin and } \\
250 \quad \mu \mathrm{M} \\
\text { manganese }\end{array}$ & $\begin{array}{l}\text { Curcumin prevented } \\
\text { manganese-induced microglial } \\
\text { cell death through the induction } \\
\text { of HO-1 and regulation of } \\
\text { oxidative stress, mitochondrial }\end{array}$ & (57) \\
\hline
\end{tabular}




\begin{tabular}{|l|l|l|l|l|l|}
\hline & & & & $\begin{array}{l}\text { dysfunction, and apoptotic } \\
\text { events. }\end{array}$ & \\
\hline $\begin{array}{l}\text { Zhu et al. } \\
(2004)\end{array}$ & $\begin{array}{l}\text { Primary cortical } \\
\text { neurons culture }\end{array}$ & $\begin{array}{l}\text { Curcumin and } \\
\text { tBHP }\end{array}$ & $\begin{array}{l}2.5-20 \mu \mathrm{M} / \mathrm{L} \\
\text { curcumin for } \\
18 \mathrm{~h} \text { and } 100 \\
\mu \mathrm{M} / \mathrm{L} \text { tBHP } \\
\text { for } 60 \mathrm{~min}\end{array}$ & $\begin{array}{l}\text { Curcumin treatment prevented } \\
\text { cellular GSH and decreased } \\
\text { intracellular ROS generation, } \\
\text { and also attenuated tBHP- } \\
\text { induced apoptosis in cortical } \\
\text { neurons. }\end{array}$ & \\
& & &
\end{tabular}


Table 2. Effects of Curcumin on Mitochondria Function on NDs in vivo.

\begin{tabular}{|c|c|c|c|c|c|}
\hline Author & $\begin{array}{l}\text { Species and cell } \\
\text { type }\end{array}$ & Agents & Dose/route & In vivo effects & Refs. \\
\hline $\begin{array}{l}\text { Jiang et al. } \\
(2011)\end{array}$ & $\begin{array}{l}\text { male mice }\left(\mathrm{Nrf}^{+} /^{+}\right. \\
\text {and } \\
\left.\mathrm{Nrf}^{-/^{-}}\right) \text {and their } \\
\text { primary spinal cord } \\
\text { astrocytes }\end{array}$ & Curcumin & $\begin{array}{l}\text { Dose- and time- } \\
\text { dependent } \\
\text { manner }\end{array}$ & $\begin{array}{l}\text { Curcumin activated Nrf2 and } \\
\text { Nrf2 target genes in primary } \\
\text { astrocytes, decreased the } \\
\text { level of intracellular ROS, } \\
\text { and attenuated oxidative } \\
\text { damage and mitochondrial } \\
\text { dysfunction. }\end{array}$ & (127) \\
\hline $\begin{array}{l}\text { Atamna et al. } \\
\text { (2006) }\end{array}$ & $\begin{array}{l}\text { Mouse model of } \\
\text { AD and SH-SY5Y } \\
\text { cell line }\end{array}$ & Curcumin & $\begin{array}{l}\text { Dose- and time- } \\
\text { dependent } \\
\text { manner }\end{array}$ & $\begin{array}{l}\text { Curcumin reduced oxidative } \\
\text { stress in a mouse model for } \\
A D \text { of } A \beta \text {-heme. }\end{array}$ & (131) \\
\hline $\begin{array}{l}\text { Sood et al. } \\
(2011)\end{array}$ & $\begin{array}{l}\text { Sprague-Dawley } \\
\text { rats }\end{array}$ & $\begin{array}{l}\text { Curcumin and } \\
\text { aluminum }\end{array}$ & $\begin{array}{l}\text { Oral gavage of } \\
100 \mathrm{mg} / \mathrm{kg} \text { body } \\
\text { wt/day } \\
\text { aluminum, and } \\
50 \quad \mathrm{mg} / \mathrm{kg} \\
\text { curcumin } \\
\text { intraperitoneall } \\
\text { y administration }\end{array}$ & $\begin{array}{l}\text { Curcumin supplementation } \\
\text { to aluminum-treated rats } \\
\text { significantly normalized the } \\
\text { activities of all the three } \\
\text { mitochondrial complexes } \\
\text { (complex I, II, IV) and } \\
\text { reduced the content of GSH } \\
\text { in the brain which wase } \\
\text { altered following aluminum } \\
\text { treatment. }\end{array}$ & $(126)$ \\
\hline $\begin{array}{l}\text { Motaghinejad } \\
\text { a et al. (2017) }\end{array}$ & Male wistar rats & $\begin{array}{l}\text { Curcumin and } \\
\text { alcohol }\end{array}$ & $\begin{array}{l}\text { Dose- and time- } \\
\text { dependent } \\
\text { manner }\end{array}$ & $\begin{array}{l}\text { Curcumin demonstrated } \\
\text { neuro- and mitochondria- } \\
\text { protection via reversing the } \\
\text { withdrawal effects of the } \\
\text { alcohol-induced cell } \\
\text { degeneration, and improving } \\
\text { neuronal survival by } \\
\text { reducing apoptosis, } \\
\text { oxidative stress, } \\
\text { neuroinflammation and } \\
\text { perturbation in CREB- } \\
\text { BDNF signaling. }\end{array}$ & (54) \\
\hline $\begin{array}{l}\text { Hagl et al. } \\
(2015)\end{array}$ & NMRI mice & $\begin{array}{l}\text { Curcumin } \\
\text { micelles }\end{array}$ & $\begin{array}{l}\text { Orally } \text { gavaged } \\
\text { of } 1.75 \quad \mu \mathrm{L} \\
\text { curcumin } \\
\text { micelles } \\
\text { solution } \quad \text { per } \\
\text { gram body } \\
\text { weight }\end{array}$ & $\begin{array}{l}\text { Curcumin micelles } \\
\text { prevented mitochondria } \\
\text { from swelling and was a } \\
\text { suitable substance for the } \\
\text { prevention of mitochondrial } \\
\text { dysfunction and } \\
\text { neurodegeneration. }\end{array}$ & (43) \\
\hline $\begin{array}{l}\text { Sandhir et al. } \\
\text { (2014) }\end{array}$ & Female Wistar rats & $\begin{array}{l}\text { Curcumin } \\
\text { encapsulated } \\
\text { solid lipid } \\
\text { nanoparticles } \\
\text { (CSLNs) }\end{array}$ & $\begin{array}{l}\text { Dose- and time- } \\
\text { dependent } \\
\text { manner, i.p. } \\
\text { administration }\end{array}$ & $\begin{array}{l}\text { CSLNs demonstrated a } \\
\text { significant increase in the } \\
\text { activity of mitochondrial } \\
\text { complexes and cytochrome } \\
\text { levels, also restored the GSH }\end{array}$ & (44) \\
\hline
\end{tabular}




\begin{tabular}{|c|c|c|c|c|c|}
\hline & & & & $\begin{array}{l}\text { levels and superoxide } \\
\text { dismutase activity and } \\
\text { significantly reduced the } \\
\text { mitochondrial swelling, lipid } \\
\text { peroxidation, protein } \\
\text { carbonyls and ROS. }\end{array}$ & \\
\hline $\begin{array}{l}\text { Eckert et al. } \\
\text { (2013) }\end{array}$ & $\begin{array}{l}\text { Senescence- } \\
\text { accelerated mice }\end{array}$ & Curcumin & $\begin{array}{l}0.5 \mathrm{~g} \text { curcumin } \\
\text { per kg diet for } 5 \\
\text { months. }\end{array}$ & $\begin{array}{l}\text { Curcumin restored } \\
\text { mitochondrial function by } \\
\text { induction of the nuclear } \\
\text { receptor PGC1a, and maybe } \\
\text { a promising dietary agent } \\
\text { that may slow down brain } \\
\text { aging and prevent } \\
\text { mitochondrial dysfunction. }\end{array}$ & $(132)$ \\
\hline $\begin{array}{l}\text { Wang et al. } \\
\text { (2005) }\end{array}$ & $\begin{array}{l}\text { male Mongolian } \\
\text { gerbils }\end{array}$ & Curcumin & $\begin{array}{l}\text { i.p. } \\
\text { administration } \\
\text { of } 30 \mathrm{mg} / \mathrm{kg} \text { bwt }\end{array}$ & $\begin{array}{l}\text { Curcumin administration } \\
\text { significantly attenuated } \\
\text { ischemia-induced neuronal } \\
\text { death, glial activation and } \\
\text { decreased lipid peroxidation, } \\
\text { mitochondrial dysfunction, } \\
\text { and the apoptotic indices. }\end{array}$ & (55) \\
\hline $\begin{array}{l}\text { Seo et al. } \\
(2010)\end{array}$ & Tg2576 mice & Curcumin & $500 \mathrm{ppm}$ & $\begin{array}{l}\text { Curcumin reversed motor } \\
\text { function deficits of Tg2576 } \\
\text { mice. Moreover, the } \\
\text { enhanced lipid peroxidation } \\
\text { and neuronal loss were } \\
\text { partially suppressed by } \\
\text { curcumin. }\end{array}$ & (133) \\
\hline $\begin{array}{l}\text { Zhang et al. } \\
\text { (2017) }\end{array}$ & $\begin{array}{l}\text { Male albino, Wistar } \\
\text { rats }\end{array}$ & Curcumin & $25 \mathrm{mg} / \mathrm{kg}$ bwt & $\begin{array}{l}\text { Curcumin reduced the brain } \\
\text { edema and water content, the } \\
\text { level of IL-6 and TNF- } \\
\alpha \text {, Protein expression of p53 } \\
\text { and Bax, and } \Delta \Psi \mathrm{m}\end{array}$ & (134) \\
\hline $\begin{array}{l}\text { Waseem et al. } \\
\text { (2016) }\end{array}$ & Male Wistar rats & $\begin{array}{l}\text { Curcumin and } \\
\text { quercetin }\end{array}$ & $\begin{array}{l}\text { Dose-dependent } \\
\text { manner }\end{array}$ & $\begin{array}{l}\text { Curcumin and quercetin } \\
\text { showed neuroprotective } \\
\text { effects and regulated the } \\
\text { neurotoxic effects of } \\
\text { oxaliplatin exposure; they } \\
\text { also attenuated oxidative } \\
\text { stress as evident by } \\
\text { mitochondrial dysfunction. }\end{array}$ & (114) \\
\hline $\begin{array}{l}\text { Banji et al. } \\
\text { (2014) }\end{array}$ & $\begin{array}{l}\text { Sixteen-week old } \\
\text { healthy Wistar rats }\end{array}$ & $\begin{array}{l}\text { Curcumin, D- } \\
\text { galactose and } \\
\text { hesperidin }\end{array}$ & $\begin{array}{l}150 \mathrm{mg} / \mathrm{kg} \quad \mathrm{D}- \\
\text { galactose } \\
\text { subcutaneously } \\
50 \text { and } 100 \\
\mathrm{mg} / \mathrm{kg} \text { curcumin } \\
\text { orally; } 10 \text { and } \\
25 \quad \mathrm{mg} / \mathrm{kg}\end{array}$ & $\begin{array}{l}\text { Curcumin reduced the levels } \\
\text { of oxidized lipids, proteins, } \\
\text { cleaved caspase-3 } \\
\text { expression and } \\
\text { mitochondrial enzymes. } \\
\text { Moreover, the combination } \\
\text { of curcumin and hesperidin }\end{array}$ & (49) \\
\hline
\end{tabular}




\begin{tabular}{|c|c|c|c|c|c|}
\hline & & & $\begin{array}{l}\text { hesperidin } \\
\text { orally }\end{array}$ & $\begin{array}{l}\text { protected the morphological } \\
\text { facets and improve the } \\
\text { biochemical functions of } \\
\text { neurons. }\end{array}$ & \\
\hline $\begin{array}{l}\text { Khatri et al. } \\
(2016)\end{array}$ & $\begin{array}{l}\text { Swiss albino male } \\
\text { mice }\end{array}$ & $\begin{array}{l}\text { Curcumin and } \\
\text { rotenone }\end{array}$ & $\begin{array}{l}1 \quad \mathrm{mg} / \mathrm{kg} \\
\text { rotenone i.p. } \\
\text { administration } \\
\text { and } 50,100 \text { and } \\
200 \mathrm{mg} / \mathrm{kg} \text { of } \\
\text { curcumin oral } \\
\text { administration }\end{array}$ & $\begin{array}{l}\text { Curcumin treatment } \\
\text { markedly improved the } \\
\text { rotenone-induced behavioral } \\
\text { alterations, oxidative } \\
\text { damage and mitochondrial } \\
\text { enzyme complex activities } \\
\text { as compared to negative } \\
\text { control (rotenone treated) } \\
\text { group, and demonstrated } \\
\text { neuroprotective effects on } \\
\text { PD. }\end{array}$ & (118) \\
\hline $\begin{array}{l}\text { Chang et al. } \\
\text { (2015) }\end{array}$ & $\begin{array}{l}\text { male Sprague- } \\
\text { Dawley rats }\end{array}$ & Nanocurcumin & $\begin{array}{l}75 / 150 / 300 \\
\mu \mathrm{g} / \mathrm{kg} / \text { day }\end{array}$ & $\begin{array}{l}\text { Nanocurcumin exerted its } \\
\text { neuroprotective effects } \\
\text { through the upward } \\
\text { regulation of NF-kB (p65) } \\
\text { and reduced mitochondrion } \\
\text { related } \\
\text { expression }\end{array}$ & (46) \\
\hline
\end{tabular}

